\title{
Analysis of Utilization of Bisphosphonates, Strontium Ranelate and Denosumabe in Serbia, Finland, Norway and Denmark in the Period 2013 - 2016
}

\author{
Đurđa M. Cvjetković, Sara M. Cvjetković-Nedeljković, Nikola B. Martić, \\ Ana J. Sabo, Zdenko S. Tomić, Boris Ž. Milijašević
}

Department of Pharmacology, Toxicology and Clinical Pharmacology, Faculty of Medicine

Novi Sad, University of Novi Sad, Novi Sad, Vojvodina, Serbia

\section{SUMMARY}

Introduction: Osteoporosis is the most common metabolic bone disease.

Aim: This study aimed to measure the utilization of drugs affecting bone structure and mineralization in Serbia from 2013 to 2016, and to compare this data with that from countries with well-developed pharmacotherapeutic practice, such as Finland, Norway, and Denmark.

Methods: The utilization of drugs is estimated using the Anatomical Therapeutic Chemical/Defined Daily Dose (DDD) methodology. The amount of total drugs consumed has been expressed in the number of Defined Daily Dose on 1000 inhabitants per day (DDD/1000 inhabitants/day).

Results: In 2016, a total of 2.91 DDD/1000 inh/day of all drugs was used in Serbia of which $75.26 \%$ belonged to bisphosphonates, whereas they made $37.15 \%$ in Finland, $81.56 \%$ in Norway and $77.84 \%$ in Denmark of the total utilization of M05 drugs subclass. The most frequently used bisphosphonate in Serbia in 2013 was alendronic acid, while in 2016 it was ibandronic acid. In three compared countries the rate of utilization among bisphosphonates was the highest for alendronic acid. The level of other bisphosphonates' utilization in Serbia, as well as the utilization of strontium ranelate, is constantly low compared to other drugs. In comparison to other countries, the utilization of denosumab in Serbia is multiple folds lower, however with an upward trend. Conclusions: The utilization of drugs affecting bone structure and mineralization in the examined period in Serbia compared to Finland, Norway and Denmark is three to six fold lower. Furthermore, there is a difference between the structure of prescribed and consumed drugs.

Keywords: osteoporosis, bisphosphonates, denosumab, utilization of drugs, pharmacoepidemiology 


\section{INTRODUCTION}

Osteoporosis is the commonest metabolic bone disease. It is believed that almost every second woman and every fifth man above 50 years of age will suffer a fracture caused by osteoporosis [1]. All fractures are associated with greater morbidity, whereas hip fractures are associated with greater mortality. Every fifth woman above 50 years of age that has suffered hip fracture dies within one year after the fracture. Therefore early detection, prevention, and rational treatment are of great importance not only for an individual but for the entire population - it should be one of the national health priorities at the primary health-care level [2].

According to the definition of the Consensus Development Conference from 1993, "osteoporosis is a progressive, systemic, skeletal disease characterized by low bone density and microarchitectural deterioration in the bone that predisposes patients to increased bone fragility and fracture". By the age of 35 or 40 bone density naturally begins to weaken. The rate of mineral loss is $0,3-0,5 \%$ per year. Besides postmenopausal estrogen deficiency, major risk factors for osteoporosis include early natural or surgical menopause (before the age of 45), hysterectomy with at least one ovary retained before the age of 45 , positive family history for osteoporosis and fractures (especially mother's hip fracture history), white race, gracile body type, long-term immobilization, long-term drug utilization (prednisone or equivalent $5 \mathrm{mg} /$ day for at least three months), low calcium and vitamin D intake, sedentary lifestyle, physical inactivity, smoking, alcohol utilization [1-3].

The most common osteoporotic fractures are those of the distal forearm, spine, and hip. Risk factors for fractures are low bone mineral density (BMD), advanced age, female gender, previous falls, weak muscles, poor balance, conditions and medications affecting cognitive function, gait and balance $[1,4]$. The gold standard for diagnosing osteoporosis, fracture risk prediction and for monitoring of treatment response is the evaluation of bone mineral density - BMD that is primarily determined by bone mineral content $[1-3,5]$.

Along with nonpharmacological measures, pharmacologic therapy is indicated in patients with a T-score equal to or worse than -2.5, in patients who have had an osteo- porosis-related fracture or in patients with a T-score between -1.0 and -2.5 between -1.0 and -2.5 combined with or high fracture probability. Prior to initiating treatment, patients should be evaluated for secondary causes of osteoporosis [5]. Pharmacological interventions can be classified into antiresorptive agents that prevent bone resorption and anabolic agents that help in the new bone formation. Antiresorptive agents include bisphosphonates, hormone replacement therapy (HRT), selective estrogen receptor modulators (SERM), and denosumab [6]. Anabolic agents include teriparatide, bone growth factors, growth hormone. There are also medications both with the antiresorptive and anabolic mechanism of action (strontium ranelate) [2,7]. The most commonly used agents in Europe are bisphosphonates (alendronic, ibandronic, risedronic and zoledronic acid), denosumab, teriparatide, strontium ranelate, raloxifene. Hormone replacement therapy (HRT) is used for both prevention and treatment of postmenopausal osteoporosis. However, it is not the first-choice treatment. Considering the progressive development of pharmacotherapy, new effective osteoporosis treatment options are anticipated [8].

\section{AIM}

The aim of this study was to measure the utilization of drugs affecting bone structure and mineralization in Serbia from 2013 to 2016 and to compare with countries with well-developed pharmacotherapeutic practice, such as the Norway, Finland, and Denmark.

\section{METHODS}

We conducted a descriptive retrospective pharmacoepidemiological study based on data already placed in the public domain by the regulatory authorities, therefore no Ethical Committee or Agency approval for conducting the study was obligatory.

Drug utilization and price data in the Republic of Serbia in the period 2013 2016 were collected from the official website of Medicines and Medical Devices Agency of Serbia and official website of National Health Insurance Fund of Serbia [9-12].

Drug utilization and price data in the 
Kingdom of Norway in the period $2013-2016$ were collected from the official website of the Norwegian Institute for Public Health [13].

Drug utilization and price data in the Republic of Finland in the period 2013 2016 were collected from the official website of Finnish Medicines Agency - Fimea [14-17].

Drug utilization and price data in the Kingdom of Denmark in the period 2013 - 2016 were collected from official website of The Danish Health Data Authority - Sundhedsdatastyrelsen [18].

The utilization of drugs is estimated using the Anatomical Therapeutic Chemical/ Defined Daily Dose (DDD) methodology. Defined Daily Dose (DDD) is a statistical measure that represents an assumed average maintenance dose per day for a drug used for its main indication in adults. The amount of total drug utilization has been expressed in the number of Defined Daily Dose on 1000 inhabitants per day (DDD/1000 inhabitants/day). The parameter DDD per 1000 inhabitants per day gives an insight into the number of inhabitants that used a certain drug and were exposed to its effect during one day [19]. The results regarding drug utilization in the Republic of Serbia, the
Kingdom of Norway, the Republic of Finland and the Kingdom of Denmark are presented in a tabular form.

The Anatomical Therapeutic Chemical (ATC) Classification System is based on a combination of seven alphanumeric characters that represent the International Nonproprietary Name (INN) - an official generic and non-proprietary name given to a pharmaceutical drug or an active ingredient [20].

This type of study includes data already placed in the public domain by the regulatory authorities, so no patient consent or agency approval for data protection is needed.

Apart from descriptive statistics, formal statistical analyses were not used. Data are presented in tables.

\section{RESULTS}

In Serbia, the utilization of bisphosphonates predominates and their utilization increased from 2.25 DDD/1000 inhabitants/day or $69.23 \%$ of the utilization of all drugs affecting bone structure and mineralization (M05B) in 2013 to $2.89 \mathrm{DDD} / 1000$ inhabitants/day or $82.57 \%$ in 2015 (Table 1). However, in 2016

\begin{tabular}{|c|c|c|c|c|c|c|c|c|}
\hline \multirow{3}{*}{$\begin{array}{c}\text { Country } \\
\text { Year } \\
\text { ATC group }\end{array}$} & \multicolumn{8}{|c|}{ Serbia } \\
\hline & \multicolumn{2}{|c|}{2013} & \multicolumn{2}{|c|}{2014} & \multicolumn{2}{|c|}{2015} & \multicolumn{2}{|c|}{2016} \\
\hline & DDD & $\%$ & DDD & $\%$ & DDD & $\%$ & DDD & $\%$ \\
\hline M05 & 3.25 & 100.00 & 2.98 & 100.00 & 3.50 & 100.00 & 2.91 & 100.00 \\
\hline M05B & 3.25 & 100.00 & 2.98 & 100.00 & 3.50 & 100.00 & 2.91 & 100.00 \\
\hline M05BA & 2.25 & 69.23 & 2.04 & 68.46 & 2.89 & 82.57 & 2.19 & 75.26 \\
\hline M05BA02 & 0.001 & 0.03 & 0.00083 & 0.0278 & 0.001 & 0.03 & 0.00116 & 0.04 \\
\hline М05ВА03 & 0.00 & 0.00 & 0.00022 & 0.007 & 0.00 & 0.00 & 0.00006 & 0.00 \\
\hline M05BA04 & 1.52 & 46.77 & 0.96 & 32.21 & 1.39 & 39.71 & 0.23 & 7.90 \\
\hline M05BA06 & 0.73 & 22.46 & 1.08 & 36.24 & 1.49 & 42.57 & 1.95 & 67.00 \\
\hline M05BA07 & - & - & - & - & - & - & - & - \\
\hline M05BA08 & 0.001 & 0.03 & 0.0014 & 0.0469 & 0.002 & 0.057 & 0.00274 & 0.09 \\
\hline М05BВ & 0.93 & 28.61 & 0.87 & 29.19 & 0.57 & 16.285 & 0.66 & 22.68 \\
\hline М05ВВ03 & 0.93 & 28.61 & 0.87 & 29.19 & 0.57 & 16.285 & 0.66 & 22.68 \\
\hline M05BX & 0.08 & 2.46 & 0.07 & 2.35 & 0.045 & 1.285 & 0.06 & 2.06 \\
\hline М05BХ03 & 0.07 & 2.15 & 0.05 & 1.68 & 0.01 & 0.285 & 0.01 & 0.34 \\
\hline M05ВХ04 & 0.01 & 0.09 & 0.02 & 0.67 & 0.03 & 0.86 & 0.05 & 1.72 \\
\hline
\end{tabular}

there was a decrease in their utilization, which was $2.19 \mathrm{DDD} / 1000$ inhabitants/day or $75.26 \%$ of all drugs from the ATC M05B subgroup. Among all bisphosphonates, the utilization of ibandronic acid was continuously increasing during the examined period and in 2013 it was $0.73 \mathrm{DDD} / 1000$ inhabitants/day or $22.46 \%$, whereas in 2016 it was $1.95 \mathrm{DDD} / 1000$ inhabitants/day or $67 \%$ of the total utilization. The utilization of denosumab also increased from $0.01 \mathrm{DDD} / 1000$ inhabitants/day or $0.09 \%$ in the year 2013 to $0.05 \mathrm{DDD} / 1000$ inhabitants/ day or $1.72 \%$ of the total utilization in the year 2016, as well as the utilization of zoledronic
Table 1. Utilization of drugs affecting bone structure and mineralization in Serbia in the period 2013-2016, expressed in $\mathrm{DDD} / 1000$ inhabitants/day and in percentages (\%)

M05 - Drugs for treatment of bone diseases

M05B - Drugs affecting bone structure and mineralization M05BA - Bisphosphonates M05BA02 - clodronic acid M05BA03 - pamidronic acid M05BA04 - alendronic acid M05BA06 - ibandronic acid M05BA07 - risedronic acid M05BA08 - zoledronic acid M05BB - Bisphosphonates. combinations

M05BB03 - alendronic acid and cholecalciferol

M05BX - Other drugs affecting bone structure and mineralization

M05BX03 - strontium ranelate M05BX04 - denosumab DDD - Daily Defined Dose/1000 inhabitants/day 
Table 2. Utilization of drugs affecting bone structure and mineralization in Finland in the period 2013-2016. expressed in DDD/1000 inhabitants/day and in percentages $(\%)$

M05 - Drugs for treatment of bone diseases

M05B - Drugs affecting bone structure and mineralization M05BA - Bisphosphonates M05BA02 - clodronic acid M05BA03 - pamidronic acid M05BA04 - alendronic acid M05BA06 - ibandronic acid M05BA07 - risedronic acid M05BA08 - zoledronic acid M05BB - Bisphosphonates. combinations

M05BB03 - alendronic acid and cholecalciferol

M05BX - Other drugs affecting bone structure and mineralization

M05BX03 - strontium ranelate M05BX04 - denosumab DDD - Daily Defined Dose/1000 inhabitants/day

Table 3. Utilization of drugs affecting bone structure and mineralization in Norway in the period 2013-2016. expressed in DDD/1000 inhabitants/day and in percentages $(\%)$

M05 - Drugs for treatment of bone diseases

M05B - Drugs affecting bone structure and mineralization M05BA - Bisphosphonates M05BA02 - clodronic acid M05BA03 - pamidronic acid M05BA04 - alendronic acid M05BA06 - ibandronic acid M05BA07 - risedronic acid M05BA08 - zoledronic acid M05BB - Bisphosphonates. combinations

M05BB03 - alendronic acid and cholecalciferol

M05BX - Other drugs affecting bone structure and mineralization

M05BX03 - strontium ranelate M05BX04 - denosumab

DDD - Daily Defined Dose/1000 inhabitants/day

\begin{tabular}{|c|c|c|c|c|c|c|c|c|}
\hline \multirow{3}{*}{\begin{tabular}{|c|} 
Country \\
Year \\
ATC group \\
\end{tabular}} & \multicolumn{8}{|c|}{ Finland } \\
\hline & \multicolumn{2}{|c|}{2013} & \multicolumn{2}{|c|}{2014} & \multicolumn{2}{|c|}{2015} & \multicolumn{2}{|c|}{2016} \\
\hline & DDD & $\%$ & DDD & $\%$ & DDD & $\%$ & DDD & $\%$ \\
\hline M05 & 11.27 & 100.00 & 11.47 & 100.00 & 11.88 & 100.00 & 11.01 & 100.00 \\
\hline M05B & 11.27 & 100.00 & 11.47 & 100.00 & 11.88 & 100.00 & 11.01 & 100.00 \\
\hline M05BA & 5.49 & 48.71 & 5.16 & 44.99 & 4.71 & 39.65 & 4.09 & 37.15 \\
\hline M05BA02 & 0.07 & 0.62 & 0.06 & 0.52 & 0.04 & 0.34 & 0.03 & 0.27 \\
\hline M05BA03 & 0.00 & 0.00 & 0.00 & 0.00 & 0.00 & 0.00 & 0.00 & 0.00 \\
\hline M05ВА04 & 2.86 & 25.38 & 2.86 & 24.93 & 2.75 & 23.15 & 2.48 & 22.52 \\
\hline M05BA06 & 1.27 & 11.27 & 1.11 & 9.68 & 0.90 & 7.58 & 0.77 & 6.99 \\
\hline M05BA07 & 1.28 & 11.36 & 1.13 & 9.85 & 1.01 & 8.50 & 0.81 & 7.36 \\
\hline M05BA08 & 0.01 & 0.09 & 0.01 & 0.09 & 0.01 & 0.08 & 0.01 & 0.09 \\
\hline M05BВ & 0.84 & 7.45 & 0.62 & 5.41 & 0.49 & 4.12 & 0.37 & 3.36 \\
\hline М05ВВ03 & 0.84 & 7.45 & 0.62 & 5.41 & 0.49 & 4.12 & 0.37 & 3.36 \\
\hline M05BX & 4.94 & 43.83 & 5.69 & 49.61 & 6.68 & 56.23 & 6.55 & 59.49 \\
\hline М05BХ03 & 0.45 & 3.99 & 0.14 & 1.22 & 0.08 & 0.67 & 0.06 & 0.54 \\
\hline М05ВХ04 & 4.49 & 39.84 & 5.55 & 48.39 & 6.60 & 55.56 & 6.49 & 58.95 \\
\hline
\end{tabular}

acid which was $0.001 \mathrm{DDD} / 1000$ inhabitants/ day or $0.03 \%$ in 2013 and $0.002 \mathrm{DDD} / 1000$ inhabitants/day or $0.09 \%$ of the total utilization in 2016. On the other hand, the utilization of the alendronic acid decreased from 1.52 $\mathrm{DDD} / 1000$ inhabitants/day or $46.77 \%$ in 2013 to $0.23 \mathrm{DDD} / 1000$ inhabitants/day or $7.90 \%$ in

2016.

In Finland the utilization of bisphosphonates gradually decreased from 5.49 $\mathrm{DDD} / 1000$ inhabitants/day or $28.71 \%$ in the year 2013 to $4.09 \mathrm{DDD} / 1000$ inhabitants/day or $37.15 \%$ of the M05B group utilization in the year 2016 (Table 2). The most consumed

\begin{tabular}{|c|c|c|c|c|c|c|c|c|}
\hline \multirow{3}{*}{$\begin{array}{c}\text { Country } \\
\text { Year } \\
\text { ATC group }\end{array}$} & \multicolumn{8}{|c|}{ Norway } \\
\hline & \multicolumn{2}{|c|}{2013} & \multicolumn{2}{|c|}{2014} & \multicolumn{2}{|c|}{2015} & \multicolumn{2}{|c|}{2016} \\
\hline & DDD & $\%$ & DDD & $\%$ & DDD & $\%$ & DDD & $\%$ \\
\hline M05 & 10.54 & 100.00 & 10.53 & 100.00 & 10.02 & 100.00 & 9.60 & 100.00 \\
\hline M05B & 10.54 & 100.00 & 10.53 & 100.00 & 10.02 & 100.00 & 9.60 & 100.00 \\
\hline M05BA & 8.77 & 83.21 & 8.42 & 79.96 & 8.00 & 79.84 & 7.83 & 81.56 \\
\hline M05BA02 & 0.00 & 0.00 & 0.00 & 0.00 & 0.00 & 0.00 & 0.00 & 0.00 \\
\hline М05ВА03 & 0.00 & 0.00 & 0.00 & 0.00 & 0.00 & 0.00 & 0.00 & 0.00 \\
\hline М05ВА04 & 8.61 & 81.69 & 8.27 & 78.54 & 7.87 & 78.54 & 7.73 & 80.52 \\
\hline M05BA06 & 0.06 & 0.57 & 0.06 & 0.57 & 0.05 & 0.50 & 0.04 & 0.42 \\
\hline М05ВА07 & 0.09 & 0.85 & 0.07 & 0.66 & 0.06 & 0.60 & 0.05 & 0.52 \\
\hline М05ВА08 & 0.01 & 0.09 & 0.01 & 0.09 & 0.01 & 0.10 & 0.01 & 0.10 \\
\hline М05ВВ & 0.00 & 0.00 & 0.00 & 0.00 & 0.00 & 0.00 & 0.00 & 0.00 \\
\hline М05ВВ03 & - & - & - & - & - & - & - & - \\
\hline M05BX & 1.77 & 16.79 & 2.12 & 20.13 & 2.03 & 20.26 & 1.77 & 18.44 \\
\hline М05ВХ03 & - & - & - & - & - & - & - & - \\
\hline М05ВХ04 & 1.77 & 16.79 & 2.12 & 20.13 & 2.03 & 20.26 & 1.77 & 18.44 \\
\hline
\end{tabular}

bisphosphonates during the examined period were alendronic acid, followed by ibandronic and risedronic acid. Unlike bisphosphonates, utilization of denosumab has an upward trend. The utilization of this medication increased from $4.49 \mathrm{DDD} / 1000$ inhabitants/day in 2013 to $6.49 \mathrm{DDD} / 1000$ inhabitants/day in 2016.
In Norway, during the examined period, the utilization of bisphosphonates was high but with a downward tendency (Table $3)$. In the year 2013 it was $8.77 \mathrm{DDD} / 1000$ inhabitants/day or $83.21 \%$. During 2014 and 2015 it decreased to $8.42 \mathrm{DDD} / 1000 \mathrm{inh} . /$ day and $8.00 \mathrm{DDD} / 1000 \mathrm{inh} /$ day, respectively and 


\begin{tabular}{|c|c|c|c|c|c|c|c|c|}
\hline \multirow{3}{*}{$\begin{array}{c}\text { Country } \\
\text { Year } \\
\text { ATC group }\end{array}$} & \multicolumn{8}{|c|}{ Denmark } \\
\hline & \multicolumn{2}{|c|}{2013} & \multicolumn{2}{|c|}{2014} & \multicolumn{2}{|c|}{2015} & \multicolumn{2}{|c|}{2016} \\
\hline & DDD & $\%$ & DDD & $\%$ & DDD & $\%$ & DDD & $\%$ \\
\hline M05 & 16.80 & 100.00 & 17.60 & 100.00 & 18.40 & 100.00 & 18.50 & 100.00 \\
\hline M05B & 16.80 & 100.00 & 17.60 & 100.00 & 18.40 & 100.00 & 18.50 & 100.00 \\
\hline M05BA & 14.40 & 85.71 & 14.40 & 81.82 & 14.60 & 79.35 & 14.40 & 77.84 \\
\hline M05BA02 & 0.00 & 0.00 & 0.00 & 0.00 & 0.00 & 0.00 & 0.00 & 0.00 \\
\hline M05ВА03 & 0.00 & 0.00 & 0.00 & 0.00 & 0.00 & 0.00 & 0.00 & 0.00 \\
\hline M05ВА04 & 12.70 & 75.59 & 12.90 & 73.29 & 13.40 & 72.83 & 13.20 & 71.35 \\
\hline M05BA06 & 1.60 & 9.52 & 1.40 & 7.95 & 1.20 & 6.52 & 1.10 & 5.95 \\
\hline М05ВА07 & 0.10 & 0.59 & 0.10 & 0.57 & 0.10 & 0.54 & 0.10 & 0.54 \\
\hline M05BA08 & 0.00 & 0.00 & 0.00 & 0.00 & 0.00 & 0.00 & 0.00 & 0.00 \\
\hline M05BB & 0.10 & 0.59 & 0.10 & 0.57 & 0.10 & 0.54 & 0.10 & 0.54 \\
\hline М05ВВ03 & 0.10 & 0.59 & 0.10 & 0.57 & 0.10 & 0.54 & 0.10 & 0.54 \\
\hline M05BX & 2.20 & 13.09 & 3.10 & 17.61 & 3.80 & 20.65 & 4.00 & 21.62 \\
\hline М05ВХ03 & 0.10 & 0.59 & 0.10 & 0.57 & 0.10 & 0.54 & 0.00 & 0.00 \\
\hline M05BХ04 & 2.10 & 12.5 & 3.00 & 17.04 & 3.70 & 20.10 & 4.00 & 21.62 \\
\hline
\end{tabular}

finally in 2016 increased to $7.83 \mathrm{DDD} / 1000$ inhabitants/day or $81.56 \%$ of the total utilization of the subgroup. The utilization of alendronic acid was $8.61 \mathrm{DDD} / 1000$ inhabitants/ day or $81.69 \%$ in 2013 . It 2014 it slightly decreased to $8.27 \mathrm{DDD} / 1000$ inhabitants/day or $78.54 \%$. The utilization in 2015 was stable and in 2016 slightly increased. During the examined period, the utilization of ibandronic, risedronic and zoledronic acid was on a low level, with the downward trend. The combination of alendronic acid and cholecalciferol has not been registered, as well as strontium ranelate. The utilization of denosumab is generally high and stable, with the exception in 2016 when it decreased to $1.77 \mathrm{DDD} / 1000$ inhabitants/day or $18.44 \%$ of the total utilization of drugs used for treatment of bone diseases.

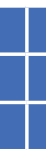

$\mathrm{S}$

\begin{tabular}{|c|}
\hline 2013 \\
1 DDD
\end{tabular}
2013

\begin{tabular}{l} 
alendronic acid \\
ibandronic acid \\
alendronic acid and cholecalciferol \\
denosumab \\
\hline Year \\
\hline Country \\
\hline Drug
\end{tabular}

alendronic acid

ibandronic acid

alendronic acid and cholecalciferol denosumab

\begin{tabular}{|c|c|c|c|c|c|c|c|}
\hline 0.32 & 0.11 & 0.30 & 0.10 & 0.30 & 0.14 & 0.25 & 0.07 \\
\hline 0.47 & 0.54 & 2.33 & 0.44 & 0.45 & 0.43 & 2.16 & 0.26 \\
\hline 0.58 & 0.65 & - & 2.80 & 0.55 & 0.66 & - & 1.20 \\
\hline 1.01 & 0.93 & 1.23 & 1.43 & 0.96 & 0.89 & 1.15 & 1.35 \\
\hline \multicolumn{5}{|c|}{2015} \\
\hline
\end{tabular}

Table 4. Utilization of drugs affecting bone structure and mineralization in Denmark in the period 2013-2016. expressed in DDD/1000 inhabitants/day and in percentages (\%)

M05 - Drugs for treatment of bone diseases

M05B - Drugs affecting bone structure and mineralization M05BA - Bisphosphonates M05BA02 - clodronic acid M05BA03 - pamidronic acid M05BA04 - alendronic acid M05BA06 - ibandronic acid M05BA07 - risedronic acid M05BA08 - zoledronic acid M05BB - Bisphosphonates. combinations

M05BB03 - alendronic acid and cholecalciferol

M05BX - Other drugs affecting bone structure and mineralization

M05BX03 - strontium ranelate

The bisphosphonates are the most M05BX04-denosumab consumed drugs among all drugs affecting bone structure and mineralization in Denmark (Table 4). Their utilization in 2013, 2015 and in 2016 it was stable - 14.40 DDD/inhabitants/day, with a mild increase in $2014-14.60$ $\mathrm{DDD} /$ inhabitants/day. The utilization of alendronic acid in the examined period increased, whereas the utilization of ibandronic acid decreased. The utilization of other bisphosphonates was on a low level or immeasurable. As for denosumab, there was an increase tendency, starting from $2013-2.10$ DDD/1000 inhabitants/day or $12.5 \%$ to $2016-4.00$ $\mathrm{DDD} / 1000$ inhabitants/day or $21.62 \%$ of the total utilization od the M05B subgroup.

According to data from Medicines and Medical Devices Agency of Serbia, aver-
DDD - Daily Defined Dose/1000 inhabitants/day 
age costs of the most commonly used drugs from the ATC M05B subgroup in Serbia alendronic, ibandronic acid, a combination of alendronic acid and cholecalciferol, denosumab - in the examined period decreased (Table 5). The same applies to the costs of the same drugs that are partially payable by the National Health Insurance Fund of Serbia (Table 6), with an exception of the combination of alendronic acid and cholecalciferol, whose cost in 2016 increased in comparison to 2013. This increase was also followed by an increase in the percentage of the patient's participation in costs from $35 \%$ to $55 \%$. Finally, one should notice that denosumab is not on the list of drugs payable by the National Health Insurance Fund of Serbia.

Table 5 shows that the price of DDD for alendronic acid during the period 20132016 in Finland increased, whereas in Norway and Denmark it gradually decreases. On the other hand, the costs of DDD for ibandronic acid in Norway increased while in Denmark and Finland decreased. In all four countries there was a slight decrease in the average cost of DDD of denosumab (with an exception in 2016) and the combination of alendronic acid and cholecalciferol.
Table 6. The average cost per defined daily dose (DDD) of most commonly used drugs af fecting bone structure and mineralization expressed in euros. and patient's participation in the cost expressed in percentage (\%) in the period 2013-2016 in the Republic of Serbia. based on data from the National Health Insurance Fund of Serbia

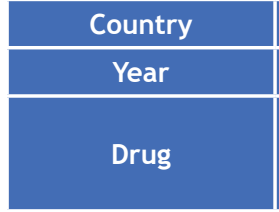

\begin{tabular}{|l} 
The wholesale \\
price per DDD \\
(EUR)
\end{tabular}

alendronic acid

ibandronic acid

alendronic acid and cholecalciferol

denosumab

\section{DISCUSSION}

The modern approach to the treatment of osteoporosis relies mostly on several groups of medications: bisphosphonates, denosumab, teriparatide, strontium ranelate, and raloxifene. Our analysis has included drugs from the ATC M05 subgroup and those are: bisphosphonates, combination of alendronic acid and cholecalciferol, denosumab and strontium ranelate. They differ from each other in dosage regimens: bisphosphonates are available in oral formulations, with daily, weekly and monthly dosage schedules and in intravenous formulations administered in three-month intervals, denosumab treatment is given subcutaneously at intervals of six months, whereas strontium ranelate is administered orally every day.

Although expressing the utilization in Defined Daily Doses has made major progress towards the evaluation of the medicine utilization, there are some limitations. The extent of prescribed or sold drugs does not necessarily correspond to the extent of the drugs actually consumed by the patients.

In Serbia, the utilization of bisphosphonates predominates. In the group of bisphosphonates, the most frequently used drug in Serbia in the beginning of the examined period was alendronic acid and its utilization represented approximately $46.77 \%$ of the total utilization of the ATC M05 subgroup. The combination of alendronic acid and cholecalciferol ranked second (28.61\%), followed by ibandronic acid - with $22.46 \%$ of the total utilization of the ATC M05 subgroup. Nevertheless, in 2016, ibandronic acid made more than half (67\%) of the total M05 subgroup utilization. In the same year, the combination of alendronic acid and cholecalciferol ranked second $(22.68 \%)$, whereas the utilization of alendronic acid was on a surprisingly low level, making no more than $7.90 \%$ of the total utilization of the drugs affecting bone structure and mineralization. This shift at the top of the utilization pyramid may be due to price changes of the drugs. Namely, in 2013 the price of DDD of ibandronic acid was higher than the price of alendronic acid's DDD. However, in 2016 it was the opposite. The differences regarding dosage regimen should also be considered: alendronic acid is administered once a week and ibandronic acid is administered orally once a month. This advantage of ibandronic acid has been also confirmed by 
BALTO study, according to which significantly more women with postmenopausal osteoporosis preferred once-monthly ibandronate therapy in comparison to once-weekly alendronate therapy, and once-monthly regimen is more convenient. Ease of complying with a treatment regimen for a long time was the most common reason given for the patients' preferences [21]. The level of other bisphosphonates' utilization in Serbia, as well as the utilization of strontium ranelate, is constantly low compared to other drugs. The same applies to Norway and Denmark as well, with the exception of Finland where except alendronic acid, zolendronic and risedronic acid are also consumed.

The combination of alendronic acid and cholecalciferol in Serbia ranked second in the examined period, unlike other three countries, where it was at the bottom. Moreover, in Norway this combination has not been registered at all. However, between 2013 and 2016 its utilization slightly decreased, unlike its price. According to data from National Health Insurance Fund of Serbia, the price of DDD of this combination was 0.21 euros in the year 2013, and in the year 2016 it was 0.27 euros. This increase in price was also followed by an increase in patients' share of medication costs from $45 \%$ to $55 \%$. That could at least partially explain the decrease of the utilization of this combination in Serbia.

Unlike Serbia, in Norway and Denmark the utilization of alendronic acid was constantly high and the highest among all drugs belonging to the ATC M05B subgroup in the examined period. However, there was a slight decrease registered over these four years. On the other hand, the utilization of denosumab increased. The same applies for Serbia, where the utilization of denosumab also increased in the examined period although it was significantly lower compared to bisphosphonates and generally on a low level compared to other three countries. Regarding the utilization of denosumab, Finland is the country that certainly stands out, since the utilization of this medication made up 39.84\% in 2013 and $58.95 \%$ of the total utilization of drugs affecting bone structure and mineralization in 2016.

By analyzing the utilization of osteoporosis medications from the financial standpoint, one can conclude that in Serbia, Norway and Denmark the most consumed drugs
- bisphosphonates, are at the same time the cheapest ones. It might be the demand that determines the price of drugs. On the other hand, the most consumed drug in Finland denosumab is the most expensive one among the analyzed drugs. However, an increase in the utilization of denosumab, as well as relative decrease in the utilization of bisphosphonates was registered in all four countries between 2013 and 2016, even in Serbia, where this medication is not on a list of medicines payable by the National Health Insurance Fund.

Opinions regarding which drug should be used as an initial therapy differ between experts. Some experts believe that denosumab should not be used as initial therapy for postmenopausal women with osteoporosis at high risk for fracture because of the availability of oral bisphosphonates, for which there are long-term safety and fracture prevention data. In addition, the bisphosphonates are less expensive. However, some other experts disagree and would use denosumab as initial therapy for women at high risk for fracture who have difficulty with the dosage requirements of oral bisphosphonates or are unwilling to take bisphosphonates. In addition, denosumab may have a role in patients with high risk fracture who are intolerant of or unresponsive to other therapies [22].

According to a 2-year DAPS study, postmenopausal women with osteoporosis were more adherent, compliant, and persistent with subcutaneous denosumab injections every 6 months than with once-weekly alendronate tablets [23]. Because of its every-sixmonths subcutaneous dosage regimen, denosumab is particularly attractive for patients who are intolerant or in whom there is concern about gastrointestinal absorption of oral agents, for elderly patients taking many other medications and for patients known to comply poorly with osteoporosis drugs. Treatment with denosumab is also appropriate in patients whose BMD is still in the osteoporosis range after several years of bisphosphonate therapy or who have completed a course of teriparatide therapy $[22,24]$.

Depending on patients' comorbidities and other used medications, oral bisphosphonates may be correlated to low absorption, adverse effects on the gastrointestinal tract (upper gastrointestinal mucosal irritation, esophagitis, esophageal ulcer or erosion, rarely esophageal stricture), musculoskeletal pain, 
inflammation of the ocular structures and in the long run they can cause jaw osteonecrosis, as well as atypical subtrochanteric fractures of the femur [25-26]. In 2010, The U.S. Food and Drug Administration warned about the possible risk of atypical thigh bone (femoral) fracture in patients who take bisphosphonates [27]. On the other hand, adverse effects of denosumab include urinary tract infections, upper respiratory tract infection and rarely jaw osteonecrosis [28].

Furthermore, the main difference between denosumab and bisphosphonates is that the first one does not accumulate in bones and its effects are reversible [29]. Unlike bisphosphonates, the skeletal effects of denosumab are quickly and completely reversible and there is no accumulation in bones. Due to that, there is no justification for a temporary interruption of therapy (so-called "drug holiday") with denosumab. If therapy is discontinued, either because of intolerance or the patient has met a treatment goal, it would be very prudent to take pharmacological measures to prevent the rapid bone loss and the return of fracture risk $[24,30]$.

There are some limitations to this study. One of them is the lack of individual patient data like age and link to patient health registers with the outcome of osteoporosis therapy. Another setback is the deficiency of prescriber's information (primary vs secondary sector).

In the absence of definitive data comparing osteoporosis therapies, treatment decisions for patients with osteoporosis should be individualized. The individual risk for fracture, presence of comorbidities, and personal preference, are important for weighing the potential benefits and risks of osteoporosis therapies [22].

\section{CONCLUSION}

Based on the results, the following conclusions can be drawn:

- The consumption of drugs used for the treatment of bone diseases including drugs used to treat osteoporosis in Serbia in the period 20132016 is multiple times lower in comparison to the other three analyzed countries. In Norway and Finland, the consumption of these medicines in the examined period is three to four times, whereas in Denmark even five to six times greater than in Serbia.
- In Serbia, the consumption of bisphosphonates predominates and their share in the total consumption of drugs affecting bone structure and mineralization (M05B) represents around $75 \%$. Bisphosphonates make around $40 \%$ in Finland and around $80 \%$ in Norway and Denmark of the total consumption of the M05 subclass.

- In the group of bisphosphonates the most frequently used drug in Serbia at the beginning of the examined period, was alendronic acid. However, at the end of the examined period the consumption of ibandronic acid takes the lead. In between-country comparisons, the alendronic acid has the highest rate of consumption amongst bisphosphonates.

- The consumption of the combination of alendronic acid and cholecalciferol in Serbia ranked second in the examined period, which differs from Finland and Denmark, where its consumption is on a low level, whereas in Norway this combination is not even registered.

- In comparison to other countries, the consumption of denosumab in Serbia is multiple times lower, making only $0.8 \%$ of the total consumption of the drugs affecting bone structure and mineralization. This percentage is much higher in other countries: in Norway and Denmark 18\%, and in Finland - 50\%. There is an upward trend of denosumab consumption registered in all four countries in the examined period

\section{ACKNOWLEDGEMENT}

This work was supported by the Ministry of Science and Technological Development, Republic of Serbia, project No. 41012 and and by the Provincial Secretariat for Science and Technological Development, Autonomous Province of Vojvodina (project No. 142-4512565/2019-02).

\section{CONFLICT OF INTEREST}

The authors deny any potential conflicts of interest.

\section{REFERENCES}

1. Lorentzon M, Cummings SR (2015) Osteoporosis: the evolution of a diagnosis. J Intern Med 277(6):650-661.

2. Ministry of Health and Social Welfare, Republic of Srpska (2004) Diseases of the musculoskel- 
etal system and connective tissue. http://www. vladars.net/sr-SP-Cyrl/Vlada/Ministarstva/MZSZ/ Documents/Osteoporoza.pdf. Accessed 08 February 2018

3. Ministry of Health of Republic of Serbia (2004) Osteoporosis: National guideline for physicians in primary health care. http://www.zdravlje.gov.rs/ downloads/2008/Sa\%20Zdravlja/dokumenta/Vodici/OSTEOPOROZA.pdf Accessed 08 February 2018

4. Bonner Jr FJ, Sinaki M, Grabois M, Shipp KM, Lane JM, Lindsay R, Gold DT, Cosman F, Bouxsein ML, Weinstein JN, Gallagher RM (2003) Health professional's guide to rehabilitation of the patient with osteoporosis. Osteoporos Int 14(2):1-22.

5. Cosman F, de Beur SJ, LeBoff MS, Lewiecki EM, Tanner B, Randall S, Lindsay R (2014) Clinician's guide to prevention and treatment of osteoporosis. Osteoporos Int 25(10):2359-81.

6. Milat F, Ebeling PR (2016) Osteoporosis treatment: a missed opportunity. Med J of Aust 205(4):185-90.

7. Gallagher JC, Tella SH (2014) Prevention and treatment of postmenopausal osteoporosis. J Steroid Biochem Mol Biol 142:155-170

8. Kanis JA, McCloskey EV, Johansson H, Cooper C, Rizzoli R, Reginster JY (2013) European guidance for the diagnosis and management of osteoporosis in postmenopausal women. Osteoporos Int 24(1):23-57.

9. Medicines and medical devices agency of Serbia (2014) The turnover and utilization of readymade drugs for human use in the Republic of Serbia in 2013. https://www.alims.gov.rs/ciril/ files/2016/03/PPL_2013.pdf Accessed 08 February 2018

10. Medicines and medical devices agency of Serbia (2015) The turnover and utilization of readymade drugs for human use in the Republic of Serbia in 2014. https://www.alims.gov.rs/ciril/ files/2017/03/PPL-2014.pdf Accessed 08 February 2018

11. Medicines and medical devices agency of Serbia (2016) The turnover and utilization of readymade drugs for human use in the Republic of Serbia in 2015. https://www.alims.gov.rs/ciril/ files/2017/07/011-Promet-lekova-2015.pdf Accessed 08 February 2018

12. Medicines and medical devices agency of Serbia (2017) The turnover and utilization of readymade drugs for human use in the Republic of Serbia in 2016. https://www.alims.gov.rs/ciril/ files/2018/08/PPL2016.pdf Accessed 08 February 2018

13. Norwegian Institute for Public Health (2017) Drug Utilization in Norway 2012-2016 http: / / www. legemiddelforbruk.no/frameset_lower_linker_e. html Accessed 08 February 2018

14. Finnish Medicines Agency (2014) Drug utiliza- tion in Finland 2013 http://www. fimea.fi/web/en/ about_us/publications Accessed 08 February 2018

15. Finnish Medicines Agency (2015) Drug utilization in Finland 2014 http: / / www. fimea.fi/web/en/ about_us/publications Accessed 08 February 2018

16. Finnish Medicines Agency (2016) Drug utilization in Finland 2015 http: / /www. fimea.fi/web/en/ about_us/publications Accessed 08 February 2018

17. Finnish Medicines Agency (2017) Drug utilization in Finland 2016 http://www. fimea.fi/web/en/ about_us/publications Accessed 08 February 2018

18. The Danish Health Data Autority (2018) Drug Utilization in Denmark 2013-2016 http://www. medstat.dk/en Accessed 08 February 2018

19. Milijašević $B$, Vlajankov $A$, Ubavić $M$, Rašković A, Martić N, Tomić Z (2018) Analysis of antidepressant use in Republic of Serbia from 2013 to 2015. Hospital Pharmacology-International Multidisciplinary Journal 5(1):607-16.

20. Jakovljević V, Stanulović M, Sabo A, Mikov M (2000) ATC - DDD - anatomical therapeutic chemical classification system of drugswith defined daily doses for drugs on the market. OrtoMedics, Novi Sad

21. Emkey R, Koltun W, Beusterien K, Seidman L, Kivitz A, Devas V, Masanauskaite D (2005) Patient preference for oncemonthly ibandronate versus once-weekly alendronate in a randomized, openlabel, cross-over trial: the Boniva Alendronate Trial in Osteoporosis (BALTO). Libraph Ltd - Curr Med Res Opin 21(12):1895-1903.

22. Rosen HN (2017) Denosumab for osteoporosis. http: //cursoenarm. net/UPTODATE/contents/mobipreview.htm?26/54/27503/abstract/2 Accessed 08 February 2018

23. Freemantle N, Satram-Hoang S, Tang ET, Kaur $P$, Macarios D, Siddhanti S, Borenstein J, Kendler DL (2012) Final results of the DAPS (Denosumab Adherence Preference Satisfaction) study: a 24-month, randomized, crossover comparison with alendronate in postmenopausal women. Osteoporos Int 23:317-326.

24. McClung MR (2017) Denosumab for the treatment of osteoporosis. Osteoporos Sarcopenia 3(1):8-17.

25. Kennel KA, Drake MT (2009) Adverse Effects of Bisphosphonates: Implications for Osteoporosis Management. Mayo Clin Proc 84(7):632-638.

26. Medicines and medical devices agency of Serbia (2014) Summary of product characteristics Bonap ${ }^{\circledR}$. https://www.alims.gov.rs/ciril/files/lekovi/smpc/515-01-04832-13-001.pdf Accessed 08 February 2018

27. FDA Drug Safety Communication: Safety update for osteoporosis drugs, bisphosphonates, and atypical fractures

https://www.fda.gov/drugs/drug-safety-and-avail- 
ability/fda-drug-safety-communication-safetyupdate-osteoporosis-drugs-bisphosphonates-andatypical Accessed 08 November 2019

28. Medicines and medical devices agency of Serbia (2011) Summary of product characteristics Pro-

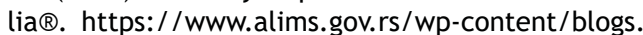
$\mathrm{dir} / 2$ /files/lekovi/smpc/515-01-5692-10-001.pdf Accessed 08 February 2018

29. Baron R, Ferrari S, Russell RG (2011) Denosum$\mathrm{ab}$ and bisphosphonates: different mechanisms of action and effects. Bone 48(4):677-92.

30. Zaheer S, LeBoff M, Lewiecki EM (2015) Denosumab for the treatment of osteoporosis. Exp Opin Drug Metab Toxicol 11(3): 461-470. 


\section{Analiza upotrebe bisfosfonata, strontium ranelata i denosumaba u Srbiji, Finskoj, Norveškoj i Danskoj u periodu 2013 - 2016}

Đurđa M. Cvjetković, Sara M. Cvjetković Nedeljković, Nikola B. Martić, Ana J. Sabo, Zdenko S. Tomić, Boris Ž. Milijašević

Katedra za farmakologiju, toksikologiju i kliničku farmakologiju, Medicinski fakultet Novi Sad, Univerzitet u Novom Sadu, Novi Sad, Vojvodina, Srbija

\section{KRATAK SADRŽAJ}

Uvod: Osteoporoza je jedna od najčešćih metaboličkih bolesti kostiju.

Cilj: Cilj rada bio je da se analizira potrošnja lekova koji deluju na strukturu kosti i mineralizaciju u periodu od 2013. do 2016. godine u Srbiji i da se dobijeni rezultati uporede sa onima u zemljama koje imaju dobro razvijenu farmakoterapijsku praksu, kao što su: Norveška, Finska, Danska.

Metod: Potrošnja lekova se zasniva na metodologiji Definisanih Dnevnih Doza (DDD) po ATC klasifikaciji. Količina potrošenih lekova izražena je u broju definisanih dnevnih doza na 1000 stanovnika na dan (DDD/1000 stanovnika/dan).

Rezultati: U 2016. u Srbiji utrošeno je 2.91/DDD/1000 stanovnika/dan, od čega 75.26\% pripada bisfosfonatima, dok oni čine $37.15 \%$ u Finskoj, $81.56 \%$ u Norveškoj i 77.84\% u Danskoj ukupne potrošnje M05 podgrupe lekova. Najviše korišćeni bisfosfonat u Srbiji u 2013. je alendronska kiselina, a u 2016. ibandronska kiselina. Potrošnja ostalih bifosfonata, kao i stroncijum ranelata je u Srbiji konstantno niska u poređenju sa ostalim lekovima. Potrošnja denosumaba je u Srbiji višestruko manja u odnosu na ostale tri zemlje, ali sa uzlaznim trendom.

Zaključak: U odnosu na Finsku, Norvešku i Dansku, potrošnja lekova koji deluju na strukturu kosti i mineralizaciju u posmatranom periodu je u Srbiji tri do šest puta manja. Takođe, postoji razlika u pogledu strukture propisivanja i konzumiranja određenih lekova.

Ključne reči: osteoporoza, bisfosfonati, denosumab, potrošnja lekova, farmakoepidemiologija 